\title{
Liminality Reimagined: Tales of Trespassers into Sacred Space and Tainted Sages
}

\author{
ABE Yasurō \\ Translated by Kristopher REEves
}

\section{INTRODUCTION}

The concept of borders or, more broadly, liminality, as it evolved within the world of Japanese culture and literature came to acquire a wide and complicated set of meanings. The challenge of participating, by way of experimental enquiry, in a comprehensive examination of the various stages along this multifaceted evolution is of special interest to scholars in the humanities. My own contribution to this ongoing project rests on a single presupposition, one which necessarily arises from a consideration of the very nature of liminality. It will be admitted that any given border is, in fact, an embodiment, that is, an effort to give a degree of visible reality to something that is otherwise intangible and invisible. That something is a complex of memories, both those memories associated with the initial conception of the border in question, as well as those memories latterly associated with the many disputes that arise throughout the history of that border. A border, then, is a symbol the function of which is to vividly bring to mind a complex of associated memories. Like memories, these borders, once established, are far from stable. Rather, borders are continually in flux, so much so that they are bound to be negated and ultimately nullified. This transformation, this appearance and disappearance of borders - a process we might refer to as the dynamism of liminality — deserves special attention. The essential nature of any border, I shall argue, lies not in any supposed stability, but rather in those aspects that are ever changing and unstable. This is the curious paradox of liminality: a border can only be properly grasped when considered as something whose delineations are not at all clear or fixed; liminality has no fixed borders. It is this paradox that I would like to examine here. Approaching the subject from a primarily anthropological perspective, I shall shift the focus from a simple discussion of borders to a more dynamic consideration of border crossings (ekkyyo 越境), that is, movement between and across liminal spaces.

Examples of border crossings are to be found most manifestly within the world of literary and performative texts. Medieval myths and folktales are especially rich 
in this respect. Vernacular tales (monogatari 物語), anecdotal literature (setsunva 説話), foundational tales of shrines and temples (engi 縁起), miraculous accounts of divine beings (genki 験記), biographies (denki 伝記), and accounts of pilgrimages (junreiki 巡礼記), along with religious scriptures and other related texts present include countless instances of movement between and across various borders. Moreover, these and many other scenes of border crossing are reenacted visually through the performative arts. In fact, one very fundamental role of the arts has been to bring these tales of border crossing into the immediate world of experienced, observable reality.

\section{Women and Sages who Cross Borders ${ }^{1}$}

\section{1-1. Trespassing into Sacred Space: Shigisan engi emaki}

Shigisan engi emaki 信貴山縁起絵巻, or the Illustrated Scroll of the Foundation of Mt. Shigi, composed sometime during the twelfth century, is an illustrated account of the founding, or rather the restoration, of a temple on Mt. Shigi 信貴山, located in the northwest of modern-day Nara. The protagonist of this work, a monk by the name of Myōren 命蓮, is portrayed as possessing a number of supernatural powers, and it is with him that we find one of the most striking examples of border crossing. The actual text of Shigisan engi emaki is more-or-less the same as that found in such collections of anecdotes and legends as Uji shüi monogatari 宇治拾遺 物語 (Collected Tales from Uji, early $13^{\text {th }}$ century) and Kobon setsuwash $\bar{u}$ 古本説話集 (Old Book of Anecdotal Tales, perhaps early $12^{\text {th }}$ century). What makes this particular scroll so special, however, is not the text itself, but rather the illustrations. After all, the written word can only do so much to convey scenes of miraculous border crossing. The illustrator of Shigisan engi emaki was employed an artist's skill and imagination to visually portray things that might have otherwise remained unexpressed in the textual realm.

Shigisan engi emaki is divided into three main fascicles. The first, which has two alternative entitles, namely, “Tobikura no maki” 飛倉巻 (The Flying Storehouse) or “Yamazaki chōja no maki” 山㟝長者巻 (The Wealthy Gentleman of Yamazaki), includes an account of how Myōren astonished everyone by making an entire storehouse full of grain soar through the sky and arrive at Mt. Shiga, all by means of a humble begging bowl. The second fascicle, entitled "Engi kaji no maki” 延喜加持巻 (Divine Protection of the Engi Emperor), shows Tsurugi no gohō dōji 鈒護法童子—one of a band of sword-bearing Buddhist divinities, usually taking the form of youthful boys, who are responsible for protecting faithful devotees-flying straight into the imperial palace in order to guard Emperor

\footnotetext{
${ }^{1}$ I have used the terms sage and ascetic more or less synonymously to translate the Japanese word hijiri 聖. Abe also uses the word gyoja 行者, literally, one who cultivates (the Buddhist way), which I have generally rendered as ascetic. The distinction, supposing there is one, between bijiri and gyoja is not raised in this article, and so I have not made any attempt to differentiate the two terms too rigorously in my own translation. [Translator's note]
} 
Daigo 醍醐天皇 (885-930, r. 897-930). It is here that Myōren's wondrous power to influence even these Buddhist divinities is visually represented with impressive skill. Finally, with the third fascicle, “Amagimi no maki” 尼公巻 (The Venerable Nun), we are treated to illustrations depicting the long journey of a nun, who happens to be Myōren's older sister, from their native land of Shinano 信濃 (modern-day Nagano) all the way to Mt. Shigi for the express purpose of seeing her beloved brother once more. One scene in particular finds this faithful nun praying fervently throughout the night before a statue of Buddha within the Hall of the Great Buddha (Daibutsuden 大仏殿) in Tōdaiji Temple 東大寺, located, like Mt. Shigi, in what is now Nara Prefecture. Not knowing where her brother might be living, she had no choice but to seek divine revelation as to his whereabouts.

Now, the way in which this nun conducts her religious supplications within the Hall of the Great Buddha is surely the most remarkable example of a border crossing to be found in this entire scroll. The precincts of this hall designated a sacred space of exceptional sanctity, ritually separated from the surrounding outside world by the strictest prohibitions. Emperor Shōmu 聖武天皇 (701-756, r. 724-749) had commissioned the construction of Tôdaiji Temple in 745. The Hall of the Great Buddha was completed in 751 . Not even his primary consort, Empress Kōmyō 光明皇后 (701-760), was permitted to step over the threshold into that most sacred hall. Once, according to Shichi daiji junrei shiki 七大寺巡礼 私記 (Private Account of a Pilgrimage to the Seven Great Temples, 1134), when she dared to set her foot within the hall, the earth was rent asunder by a sudden earthquake. Myōren's sister, however, is permitted not only to step over the threshold of the Hall of the Great Buddha, but to intone supplications before the Buddha, to sleep in front of the hall-for it was through a dream that the Buddha informed the nun of her brother's whereabouts—and finally to offer up prayers of thanksgiving after receiving this crucial revelation.

All of these actions are depicted by the artist of Shigisan engi emaki by means of a technique known as iji dōzu 異時同図, literally “different times, one picture," in which a series of successive events or actions, all performed by the same character, are shown against a single, unchanging background. On the one hand, we see the nun standing in front of the threshold of the hall, and again sleeping just outside the hall, an umbrella for her pillow. These two depictions of her represent actions performed in the real world. On the other hand, still in the same picture, we see three more depictions of the nun, all within the precincts of the sacred hall. These may be understood as representing actions performed in the dream world, when the Buddha was instructing the nun as to her brother's location (Figure 1). The last of these three dream-world depictions shows the nun gazing off in the direction of Mt. Shigi, where, so she has just been informed, her brother is to be found. From here on in, the artist of Shigisan engi emaki depicts the nun's lengthy journey to Mt. Shigi through a series of quick snapshots: Now we see, dispersed over the page here and there, her expressions of happiness 


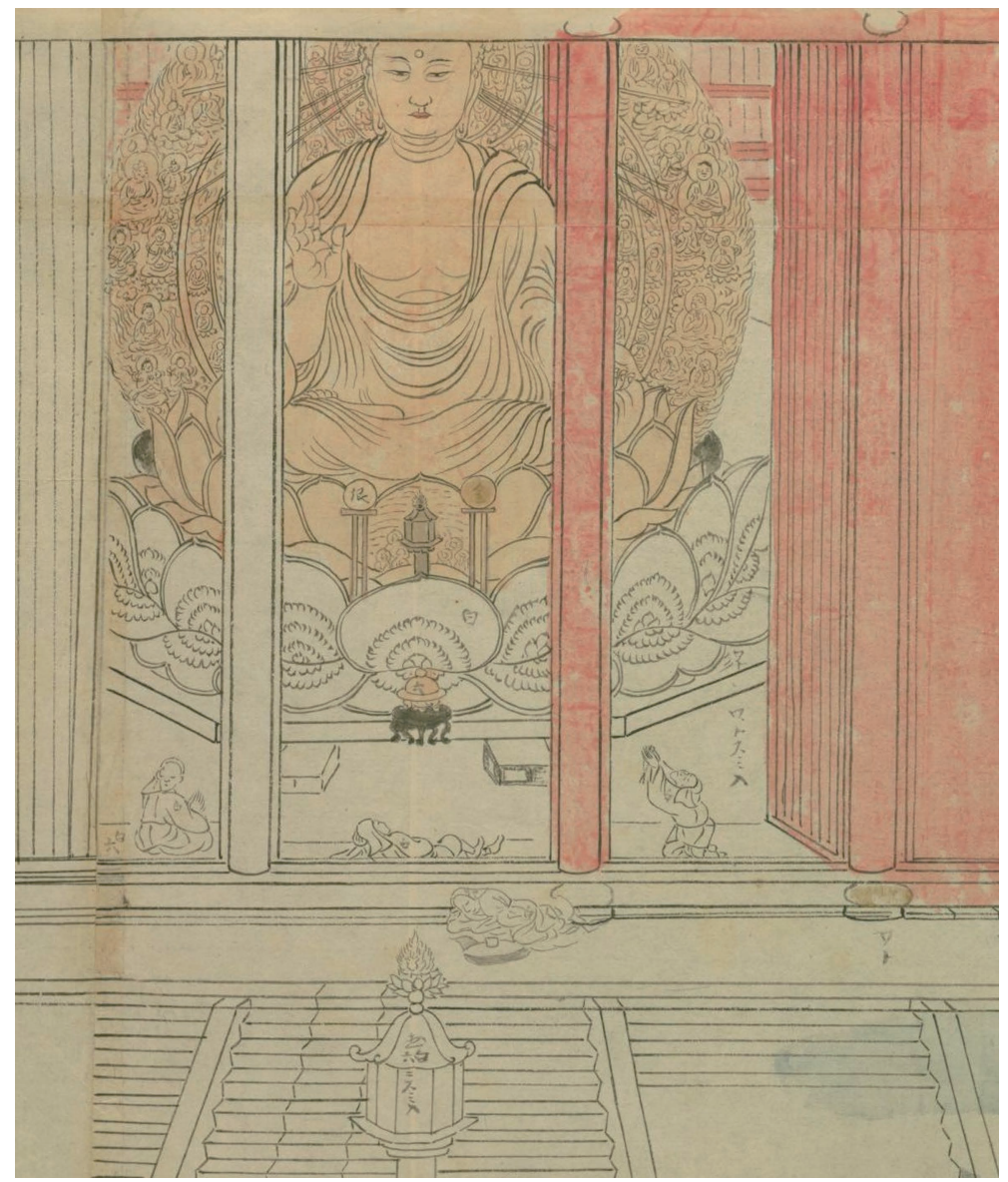

Figure 1. Illustration of Tōdaiji Temple, from Shigisan engi emaki vol. 3. (National Diet Library, Japan) https://doi.org/10.11501/2574278

along the way; now we see the nun arriving at the mountain, calling out to her brother, who, understandably surprised, has his head turned around in the direction of his sister's voice. Here the scroll ends, with the emotional reunion of brother and sister.

There is, aside from this nun's remarkable border crossing — out of the mundane world and into the sacred space of the Hall of the Great Buddhaanother equally astonishing border crossing that takes place in Shigisan engi emaki. In what may be called the epilogue to this tale, we find the nun living with her brother in his mountain abode, where she learns from him the art of reading the scriptures and presenting offerings to the Buddha. While this teacher-disciple relationship shows clear separation of the genders and their assigned roles, and while it is true that these two are siblings, even so, monastic regulations strictly forbade men and women to live together, no matter their 
relationship. Here, however, the author unabashedly portrays these two living side by side in a sanctified space, in what appears to be a blatant contradiction of Buddhist law. In the aforementioned Uji shüi monogatari, we find a tale entitled "Shinano no kuni no hijiri no koto" 信濃国聖事, or “An Account of the Sage from Shinano Province (fascicle 8, tale 3), the text of which relates directly to the relationship between Myōren, the "sage from Shinano," and his sister, the nun.

According to this tale, the nun visited her brother for one simple reason, namely, to present him with a sash or bellyband (fukutai 腹带, alternatively written 福衲) that she had woven with her own hands. She insisted, furthermore, on binding this sash about her brother's waist herself. With the sash bound about his waist, the sage of Shinano was effectively invested with the feminine power of a sister or young woman (imoto no chikara 妹の力). ${ }^{2}$ After the sage's death, continues this tale, many people desired to get their hands on fragments of this sash, which had since acquired the status of a holy relic. Since the sash itself was eventually lost, people resorted to the next best thing: One of the decaying pillars was removed from the storehouse at Mt. Shigi, the very storehouse that Myōren was supposed to have made soar through the air atop a begging bowl, and which was believed to have at one time housed the precious sash. Pieces of this pillar were then used to make miniature carvings of Bishamonten 毘沙門天 (Sk: Vaiśravana), the principal deity worshipped at the temple atop Mt. Shigi, which carvings were, in turn, handed out to pilgrims visiting the site. This tale, then, serves as an explanation or foundational account (engi) of the then contemporary belief in the miraculous efficacy of Bishamonten at Mt. Shigi to bestow blessings upon faithful pilgrims. This account appeals to a popular belief in contagious magic: the sash was once worn by a great sage, and is therefore the source of blessings; anyone who comes into contact with the sash, or something else-in this case an old pillar-which was once itself in contact with that sash, will likewise be blessed. Considering that the power of this sash is said to have had its origin in the symbolic union of a male sage and a nun, one might interpret this tale as a mythical account of the communion of sacred and secular, as well as male and female. ${ }^{3}$

It is possible to understand the above tale as a foundational account aimed at explaining the formation of a special class of sacred relics, namely those intimately connected with Buddhism. Buddhism, it must be remembered, was a religion that was not originally part of the doctrinal paradigm enshrined within

\footnotetext{
${ }^{2}$ It should be noted here that the bellyband or fukutai was, and still is, generally made for and worn by pregnant women as a charm to assist in easy delivery. That a male monk should receive this sash from a female is a potent symbolic gesture. [Translator's note]

${ }^{3}$ Kobayashi Taiichirō 小林太一郎, “Shigisan engi no bunseki一hiite sono etoki no kokoromi”" 信貴山縁起の分析一ひいてその絵解きの試み, in Bukkeyo geijutsu 仏教芸術 50:51 (1963) ; Sakurai Yoshirō 桜井好朗, “Shaji engi no sekai—kyoshiteki ni” 社寺縁起の世界一巨視的に, in Taikei bukkyō to Nihonjin 大系仏教と日本人, volume 9 (Shunjūsha, 1986).
} 
Japan's ancient system of governance by codified laws (ritsuryö kokka 律令国家). ${ }^{4}$ The formation of a class of uniquely Buddhist sacred relics was decisively set in motion by the sort of behavior attributed to the nun in Shigisan engi emaki and other closely related tales. Tōdaiji Temple was erected to serve, among other things, as a conspicuous symbol of the Buddhist faith in its then new capacity as the state religion, and, at the same time, as a symbol of imperial power, which was seen as an extension of Buddhist law. Moreover, according to Buddhist doctrine, Tōdaiji Temple was not merely a physical structure, nor simply a symbol of power, but an actual embodiment of the entire cosmos (bökai 法界). When female pilgrims and nuns began showing up at this temple unannounced, flagrantly violating the strict prohibition against women trespassing into this most sanctified of sacred spaces (nyonin kekkai 女人結界), something revolutionary was bound to happen.

Shigisan engi emaki, far from inciting this doctrinal revolution, merely reflected it in a creative visual form. According to this illustrated scroll, it was only after the nun had openly violated the prohibition against women entering the Great Hall of the Buddha that she was given the divine revelation required to discover the whereabouts of her elusive brother. Only then was she able to make her way to Mt. Shigi and, by binding the sash around her brother's waist, give birth to a sacred relic, the efficacy of which would be praised for generations of pilgrims to come. Therefore, it was only by deliberately violating the prohibition against women-by violating the sacred - that is, by crossing over and thereby effectively nullifying the border between the mundane outside world and the sacred space within the hall, that a sacred object could at last be produced. It is this paradox that is so skillfully represented in the illustrations of Shigisan engi emaki.

\section{1-2. Prohibitions against Women: Tales about Violations of Sacred Space}

Instances of border crossings preserved in Shigisan engi emaki did not occur in a vacuum; they were not simply products of an artist's imagination. Quite the contrary. Behind every example of border crossing lies, on the one hand, a countless array of legends or tales dealing with women who violated prohibitions against entering sacred spaces, and, on the other, those sacred mountains and other geographical sites whose foundational myths were themselves built up by these same tales. Generally speaking, these tales all have as their protagonist a woman who deliberately violates religious regulations against women in order

\footnotetext{
${ }^{4}$ For a recent and concise English-language account of what is commonly referred to as the ritsuryō state, see Sakaue Yasutoshi, with Kristopher Reeves, "The ritsuryō state," in Karl Friday, ed. Routledge Handbook of Premodern Japanese History (Abingdon-on-Thames: Routledge, 2017). The period of Japan's ritsuryo state is generally regarded as beginning in the year 645 and ending sometime around the middle of the tenth century. While Buddhism is thought to have come to Japan as early as the sixth century, before the establishment of the ritsuryo state, its religious doctrines were never incorporated into the framework of this system of governance, the theoretical basis of which was taken over from continental Tang legal codes. [Translator's note.]
} 
to ascend some mountain peak and enter into a sacred space located thereon. At times this woman is none other than the mother of the male founder of a given mountain temple.

Tōdaiji Temple, aside from the tale of the nun just discussed, has its own share of other similar legends. The statue of the Great Buddha at this temple was inaugurated, or, to use the proper Buddhist terminology, its eyes were opened (kaigen 開眼), in the year 752. This same year, a monk by the name of Jicchū 実忠 (726-?) —noted disciple of Master Rōben 良弁僧正 (689-774), founding patriarch of the temple-instituted a religious ceremony commonly known as the Shuni'e 修二会, literally "religious gathering of the second (lunar) month." This ritual, which takes the form of a mass confession before a statue of Jüichimen kannon 十一面観世音 (Eleven-Faced Avalokiteśvara; Sk: Avalokiteśvara-ekadaśamukha), is conducted in Nigatsudō 二月堂, the Second Moon (Month) Hall, one of many halls dedicated to a specific religious ritual found within the Tōdaiji Temple complex. The Tödaiji engi ekotoba 東大寺縁起絵詞, or Illustrated Scroll of the Foundation of Tödaiji Temple, completed in 1334, contains a foundational tale about this Shuni'e that features a female protagonist referred to as Shōe no nyonin 青衣の女人, literally, the women in the blue surplice. As the story goes, the specter of a deceased woman once took it upon herself to violate the prohibitions against women and enter into the sacred space of Nigatsudō in order to appear before a congregation of monks then engaged in conducting the annual Shuni'e rituals. The specter requested that her name be included in the temple's Register of the Departed (kakocho 過去帳) and read aloud at every Shuni'e from thereon in. Intoning the name of a departed soul is, in Buddhist contexts, a form of religious service (kuyo 供養) aimed at ensuring perpetual repose and heavenly merit for the deceased. Monks, as religious ascetics, are men who have renounced the mundane world and are subject to strict restrictions, men who, furthermore, dedicate their lives to austere and oft times severe practices. By placing such men in charge of ensuring the repose of deceased souls, women included, this tale seeks to legitimate the salvific role of monks once and for all. ${ }^{5}$

Prohibitions against women trespassing on sacred spaces, as detailed in the monastic regulations of ancient Buddhist temples, are indicative of the idea that women are, for one reason or another, essentially incompatible with the framework of these institutions. The reason for these prohibitions is often attributed to an abhorrence for blood, such as that accompanying menstruation and childbirth, and hence something uniquely female. In terms of content, tales about women breaking Buddhist prohibitions are not limited exclusively to the level of popular beliefs. An immensely famous legend about an incident that is said to

\footnotetext{
${ }^{5}$ Abe Yasurō 阿部泰郎, “Yama ni okonau hijiri to nyonin-Shigisan engi emaki to Tōdaiji Zenkōji wo megurite” 山に行う聖と女人一信貴山縁起絵巻と東大寺・善光寺をめぐりて，in Yuya no kōgō—chūsei no sei to seinaru mono 湯屋の皇后一中世の性と聖なるもの (Nagoya Daigaku Shuppankai, 1998), 246-789.
} 
have occurred at Dōjōji Temple 道成寺, located in modern-day Wakayama Prefecture, features as its protagonist a woman by the name of Kiyohime 清姫 (literally, Pure Princess), who, having fallen madly in love with a certain Buddhist monk named Anchin 安珍, pursues him up a mountain and, trespassing on sacred space, charges into the temple unannounced. ${ }^{6}$ Another variation of this motif is found in Eizan ryakeki 㕡山略記 (Abridged Records of Mt. Hiei, probably $13^{\text {th }}$ century), in which the female protagonist, likewise madly in love with a monk, resorts to defaming her unresponsive darling with false accusations.

On the other hand, there are related versions of this motif in which, to cite one example from Hikosan ruki 彦山流記 (Records of Hikosan Shrine, 1205), a male ascetic, having in his wonderings through the mountains accidentally stumbled upon a female ascetic, finds himself overcome by carnal desire. ${ }^{7}$ Here the male ascetic, having been rescued by a woman, requests to engage in sexual intercourse, claiming that kissing her lips would be a source of pollution to him. Oddly enough, it seems that, so far as the male ascetic was concerned, sexual intercourse was less polluting than kissing. ${ }^{8}$ The woman, however, manages to convince the ascetic of the paradoxical nature of his argument. No sooner does he kiss the woman than she transforms, first into a nine-headed dragon, and finally into her true form, the Eleven-Faced Avalokiteśvara. ${ }^{9}$ Aside from its sexual content, this tale closely resembles the miraculous account of the Chinese monk Xuanzang 玄焋 (J: Genjō, 602-664) and how he obtained a copy of the Heart Sutra 般若波羅蜜多心経 (Sk: Prajña-päramitā-hrdaya sütram; J: Hannya haramitta shingyo) while travelling through India. ${ }^{10}$ In fact, miraculous tales involving the manifestation of divine beings as a direct result of sexually provocative behavior between a male ascetic and a female can be traced back to Minamoto no Tamenori’s 源為憲

\footnotetext{
${ }^{6}$ This legend appears in a number of premodern sources, including Dainibon bokke genki $i$ 日 本国法華験記 (Miraculous Accounts of the Lotus Sutra in the Great Land of Japan, completed sometime between 1040 and 1044) and Konjaku monogatarishü 今昔物語集 (A Collection of Tales Old and New, sometime after 1120), both of which are anthologies of anecdotal tales and legends. The medieval nō play "Dōjōji" 道成寺 ("Dojoji Temple”), attributed to the playwright Kanze Nobumitsu 観世信光 (1435/1450-1516), is an adaptation of this same tale into a highly visual performative genre. [Translator's note]

${ }^{7}$ For the text of Hikosan ruki, see Gorai Shigeru 五来重, ed., Shugendō shiryōshüu 修験道史料集, volume 2 (Meicho shuppan, 1984), 466-467.

${ }^{8}$ The word I have rendered here as 'kiss' is a loose translation of kuchi wo sū 口を吸う, literally, sucking of the mouth, or mouth-sucking, the precise mechanics of which sadly remain a mystery. Mouth-sucking was, in all likelihood, something more than just kissing. [Translator's note]

9 Suzuki Masataka 鈴木正崇, “Kegare to nyonin kinsei”〈檅れ〉と女人禁制, in Shükyō minzoku kenkyyu 宗教民俗研究, 27(2018), 113-116.

${ }^{10}$ The earliest versions of this tale are preserved in Konjaku monogatarishü 今昔物語集, Uchigikishü 打聞集 (A Collection of Tales Just as They Were Told, 1134), and the Bunpō MS 文保本 of Shōtoku taishiden 聖徳太子伝 (Biography of Crown Prince Shōtoku, 1317-1318). For more on this subject, see Abe Yasurō 阿部泰郎, “Yuya no kōgō—Kōmyō kōgō yuswgyō no monogatari wo megurite” 湯屋の皇后一光明皇后湯施行の物語をめぐりて，in Yuya no kōgō 湯屋の皇后 (1998), 30-37, 50-56.
} 
(?-1011) Küyarui 空也昩 (Eulogy for Küya), completed near the end of the tenth century. According to this work, the ascetic Kūya 空也 (903-972) was approached by an elderly woman who, by all appearances, was stricken with a serious illness. Unbeknownst to Kūya, this was no mortal woman but an old shape-shifting fox who lived in the Shinsen Gardens (Shinsen'en 神泉苑) within the imperial compound. Küya tended to the woman with great care, providing her with both clothing and food. When she recovered, this woman then requested that Küya have sexual intercourse with her, which request the holy man is said to have granted. At this juncture, the fox reveals her true form, expressing sincere gratitude for all the ascetic has done. Incidentally, this same tale can be found in a twelfth-century work entitled Rokuharamitsuji engi 六波羅蜜寺縁起, or Foundational History of Rokuharamitsuji Temple, by Miyoshi no Tameyasu 三善為康 (1049-1139).

\section{1-3. Tales of Border Crossings and Ritual Pollution}

All of the tales discussed thus far have been of a predominantly religious character, featuring as they do a sage or ascetic man, and depicting border crossings involving some interplay between sacred and secular, male and female. It was in the world of literary texts that we saw the processes and inevitable climactic moments of these tales depicted; it was through the written word that these tales were brought to life. Literature does not merely gather up and record ancient tales. Literature has the power to stimulate the creative imagination of performers, playwrights, and other artist working in visual media, such that, through them, these tales take on a central role of their own, far beyond their original literary context.

Ritual pollution (kegare 穢) is the stigma imposed upon all women and holy men portrayed in these tales as the subjects of border crossings. The precise nature of this ritual pollution and its relationship to the protagonist is by no means straightforward; this motif can take any number of different forms. While there are certainly very simplistic forms in which the woman is viewed more-or-less as a passive receptacle of ritual pollution, there are many more examples in which the relationship between the female protagonist and ritual pollution is much more nuanced. Among the varied legends surrounding Empress Kōmyō, a figure we have already encountered in relation to the Hall of the Great Buddha, there is one relating to the Buddhist practice known as yusegyo 湯施行, or the meritorious practice of personally bathing poor and sick people who happened to come to a given temple. According to Kenkyü go junreiki $i$ 建久御巡礼記, or Record of Imperial Pilgrimages during the Kenkyü Era (completed in 1191), Empress Kōmyō made a religious vow in which she expressed a deep desire to plant the seeds of ultimate goodness before she passed away. In response to this, as a means of testing her devotion, the deities above commanded her to perform meritorious deeds to all without the slightest hint of prejudice (musa no kudoku 無差ノ功德). More specifically, she was to bathe with her own hands anyone who came her 
way, no matter what sort of person it might chance to be. Before her appeared a beggar of hideous appearance and belonging to a group of social outcasts known as saka no mono 坂者, literally, those who dwell upon the slopes. ${ }^{11}$ True to her vow, Empress Kōmyō ardently suppresses all feelings of disgust in order to scrape off the poor man's grime encrusted limbs. After she has kindly requested the man to keep this episode a secret, he, in turn, promptly replies by asking her to tell nobody that she has this very day cleansed the body of a buddha. No sooner has he revealed to Empress Kōmyō his true identity than he transforms into a divine being of light and ascends to the heavens before her eyes. Here we have a dramatic tale whose miraculous climax depends upon the simultaneous overturning of two dichotomies, namely, that of purity and pollution, and that of sacred and secular. ${ }^{12}$

As was discussed in the previous section, there are several examples of related tales in which the male ascetic willingly agrees to engage in sexual intercourse with a woman as a means of ensuring the full recovery of his patient, despite the ritual pollution consequent upon such activities. At times, an otherwise celibate sage, while expressing due hesitation at breaking his vows of chastity, nevertheless attempts to convince a woman to assist him in satisfying some newly awakened carnal desires. In these cases, it is when and only when the protagonist willingly and wholeheartedly exposes himself to the pollution of secular concupiscence that he is at last made privy to an epiphany in which the sacred is made known to him. There is something quite profound going on beneath the surface here. Ippen hijiri'e 一遍聖絵, or the Illustrated Life of Master Ippen, completed in 1298, is a medieval biography of the famous Japanese itinerant monk Ippen 一遍 (1239-1289), founder of the Jishū Society 時衆 of Pure Land Buddhism. Here, too, we are presented with a seeming paradox. Ippen's own epiphany comes in the form of an encounter with one of the avatars worshipped at Kumano Shrine, the so-called Kumano gongen 熊野権現. While sleeping, the avatar appears before Ippen, telling him that the holy gods make no distinction between the pure and the impure, nor do they place any importance whatsoever on the faith or lack thereof. Hearing these words, Ippen finally reaches enlightenment. It would appear that seemingly paradoxical episodes like this might serve as allegorical representations of a deeper Buddhist teaching. Namely, that the only path to salvation is that of abandoning all distinctions between the pure and the impure, and surrendering one's self unconditionally to the providence of Buddha.

\footnotetext{
${ }^{11}$ The term saka no mono, or those who dwell upon the slopes (or hills), refers historically to two large communities of outcasts (bi'nin 非人), one based around Kiyomizuzaka 清水坂, the Kiyomizu Slope, in Kyoto, the other around Narazaka 奈良坂, the Nara Slope, in Nara. These outcasts were responsible for dealing with the disposal of corpses, the care of those suffering from leprosy, and the reception of temple donations intended especially for outcasts (bi'nin segyo 非人施行).

${ }^{12}$ Abe Yasurō 阿部泰郎, “Yuya no kōgō—Kōmyō kōgō yusegyō no monogatari wo megurite" 湯屋の皇后一光明皇后湯施行の物語をめぐりて, in Yuya no koogoo 湯屋の皇后 (1998), 18-64.
} 


\section{Gods who Forgive and Praise the Tainted Sage}

\section{2-1. Medieval Anecdotal Tales about Tainted Sages}

I would like to focus here on those medieval anecdotal tales in which a male sage is depicted as transgressing the boundaries of purity and thereby exposing himself to the contaminating effects of ritual pollution. ${ }^{13}$ These tales are intimately bound up with the central role of sages in the world of Japanese Buddhism. Such sagely individuals are referred to variously as shami 沙弥 (Sk: śramanera), that is, a Buddhist acolyte, shōnin 聖人, one who has gained an intimate appreciation of the Four Noble Truths of Buddhism, or by the homophonous term shonin 上人, literally, one who is above or superior to normal mortals. Throughout the history of Buddhism, sages have earned the reverence of believers in one of two ways. On the one hand, there are those sages who, not satisfied at limiting themselves to meditation within the walls of a cloistered temple, go out into nature, making their way over mountains and rivers, with the express purpose of perfecting the Buddhist practice of toso 斗擻 (Sk: dhüta), that is, of completely doing away with all earthly desires for food, raiment, and shelter. These sages, having settled down in some sacred locale-often a secluded mountain — and having, through their high level of cultivation, attained certain miraculous powers, go on to worship the resident buddhas and gods of that locale. In response to the sage's earnest religious practices, these local divinities then make an appearance, thereby making their existence known once and for all. On the other hand, there are sages who voluntarily make their way into bustling cities and surrounding rural areas, mixing with the local population, intoning the salvific name of Amitābha 阿弥陀 (J: Amida), spreading the Buddhist teachings and leading the fatuous masses to enlightenment. These two categories of sages are by no means mutually exclusive. Kūya, whom we have already met, was a mixture of both.

The evolution of various religious activities carried out by such individuals, still prevalent well into the early modern period, had their roots in ancient society. ${ }^{14}$ Let us turn our attention to the intermediate stages of this evolution, that is, to the medieval period, and examine more specifically how sages crossed over borders of purity and impurity in their confrontations with potentially contaminating forces or events. Kamo no Chōmei 鴨長明 (1153/1155-1216), vernacular poet and superintendent of Shimogamo Shrine 下鴨神社 (in Kyoto), voluntarily

\footnotetext{
${ }^{13}$ The modern Sino-Japanese term for this is shokue 触穢, that is, kegare ni fureru, which refers to the act of somehow—usually physically_coming into contact with (fureru触れる) something that is deemed impure (kegare 穢れ). For the sake of brevity, I have decided to use the term "tainted sage" to refer to sages who have incurred the stigma of pollution. [Translator's note]

${ }^{14}$ Hori Ichirō 堀一郎, Küya 空也 (Yoshikawa kōbunkan,1963); Gorai Shigeru 五来重, Kōya bijiri 高野聖 (Kadokawa shoten, 1975) and Zōho Kōya hijiri 増補 高野聖 (Kadokawa shoten, 1985); Itō Yūshin 伊藤唯真, Seibukekyōshi no kenkyuy 聖仏教史の研究, in Itō Yüshin chosakushü 伊藤唯真著作集, volume 1 (Hōzōkan, 1995).
} 
abandoned his career as a courtier and, instead of taking up residence in a monastery, retired to a small hut situated in the backwoods of Kyoto, where he pursued a life of seclusion. It was Chōmei who was the first medieval writer to record tales of the sort just mentioned. His Hosshinshu $\bar{u}$ 発心集, or Tales of Religious Awakening (completed sometime before 1216) marks the beginning of medieval collections of Buddhist anecdotal tales. While earlier collections amounted to short hagiographies (ojjoden 往生伝) of famous monks who had purportedly attained rebirth into the Pure Land, Chōmei's collection went beyond this, including accounts of less known people, ancient and contemporary, who sought to renounce the world as a result of sudden religious awakening.

One such account preserved in Hosshinshiu features as its protagonist an anonymous monk who makes a vow to pay his respects to the gods at Hie Shrine 日 吉大社 (located in modern-day Ōtsu City, Shiga Prefecture) for one-hundred consecutive days. It should be noted here that Hie Shrine, also known as Hie sannō 日吉山王, or “Hie, King of the Mountain," served as an important center, both religious and political, throughout the whole of the medieval period. The monk who vowed to visit this center for one hundred days was required, therefore, to observe the most austere purity and strictest chastity; he was not to come into contact with anything that might contaminate his person. One day in the middle of his one-hundred day routine, as this monk was returning from the shrine, he chanced upon a young girl weeping by the roadside. Upon enquiry, the monk discovered that the poor girl had just recently lost her mother. Due to strict religious prohibitions against coming into contact with death and decay, however, no one in the area had offered to assist with the burial. The corpse of her mother still lay unburied. Thinking the matter over, the monk decided that since the buddhas, feeling such compassion for us mortals, deign to descend to this polluted world and appear before us in the form of myriads gods, so, too, would they forgive his act of compassion towards this poor girl; surely, considering the monk's motives, the merciful buddhas would overlook the pollution of coming into contact with a dead body. Come nightfall, he went ahead and buried the girl's mother.

Not certain whether this potentially contaminating act had technically precluded him from continuing with the remainder of his hundred-day service, the monk, deliberately transgressing conventional prohibitions, made a trip to the shrine in order to enquire of the gods directly. On his way to the shrine, the monk is moved by a profound realization: the stigma of pollution connected with childbirth and death is nothing more than an expedient means employed by the gods in order to incite proper religious reverence. In other words, so long as one remains reverential towards the gods, ritual pollution is not something that can interfere with religious practice. Despite the immediacy of this realization, the monk harbors a lingering doubt as to its authenticity. After reaching the entrance of the shrine, his troubled spirits are at last relieved by the divinely inspired words of a certain medium (kannagi $i$ 巫) in the service of 
Jūzenji 十禅師, one of the seven avatars of Hie sannō: "I observed that which you performed last night. Verily, it was a fine thing you did!" Receiving this last statement of divine approval, the monk became certain of the authenticity of his realization.

This tale was written to elucidate the real significance of prohibitions against ritual pollution, namely, that such prohibitions are expedient means used by the gods in order to cultivate faith in us mortals. It was in light of this teaching that the monk was forgiven. However, warned the god, most people are too ignorant to grasp the principles behind this teaching. If the monk were to share his new realization with laymen, he would only succeed in making them less careful about offending the gods, and hence less faithful towards them. The avatar commands the monk to keep what he has learned a secret. For the enlightened sage, who is no longer in need of expedient means, religious prohibitions are understood for what they really are: nothing more than convenient devices geared at assisting as-of-yet unenlightened humans.

\section{2-2. Gods and Sages Brought Together in Medieval Tales of Pollution}

Chōmei's Hosshinshü is not the only source for tales in which tainted sagestainted, at least, in the strictly conventional sense-are unexpectedly praised for their acts of compassion. Rather, this is a motif that runs through many a medieval Japanese anecdotal tale dealing with miraculous legends (reigentan 霊験譚) attributed to divine figures. ${ }^{15}$ Another collection of Buddhist anecdotal tales entitled Shasekishü 沙石集 (Collection of Sand and Pebbles, 1283), compiled by the monk Mujū 無住 (1227-1312), contains in its first fascicle a legend bearing the title "The Deity Offers Praise for An Act of Compassion" (Shinmei jihi wo tattobi tamau koto 神明慈悲を貴び給ふ事). This tale bears striking similarities to the one found in Hosshinshi discussed above. The protagonist of this tale is a monk named Jōkanbō 常観房 who hails from the district of Miwa 三輪 in Yamato 大和 (Nara). Jōkanbō was on his way to pay his respects to an avatar known as Zōō (Zōō gongen 蔵王権現) worshipped at Mt. Kinbu 金峯山 in the district of Yoshino 吉野, likewise situated in what is modern-day Nara. Having spied a corpse laying by the roadside, the monk takes it upon himself to see that the body is properly buried somewhere in the wilderness. Fearing that the stain of pollution has disqualified him from visiting the avatar, Jōkanbo decides to turn around and head back home. To his astonishment, however, he is unable to take even a single step in the direction of his hometown in Miwa. On the other hand, when he turns about and tries instead to continue on his way to Yoshino, he finds his steps light and easy, at which point he muses within himself: "Could it be perhaps that the deity is trying to tell me, 'Onwards! Head straight to my temple'?" As was the case with the anonymous monk in Chōmei’s tale, Jōkanbō

\footnotetext{
${ }^{15}$ Watanabe Sadamaro 渡邊貞磨, Bukkeyō bungaku no shüen 仏教文学の周縁 (Osaka: Izumi Shoin, 1994).
} 
heads towards the temple burdened with an uneasy mind, not sure whether or not the divine sign he has received is, in fact, legitimate. Then, a spirit medium possessed by the avatar Zōō greets the monk, urging him to continue to the temple: "What care I for all these prohibitions against pollution? It is compassion alone that I revere."

Shasekishü contains a number of similar tales in which the gods are described as attributing supreme value to acts of compassion, even when those acts transgress conventional religious prohibitions. Atsutamiya 熱田宮, one of the local deities worshipped in Mujü's own hometown, is recorded as forgiving those who have incurred the pollution of coming into contact with death or childbirth. It seems safe to say, therefore, that during the medieval period these legends were not limited exclusively to a specific set of deities or famous sages, but were rather attributed more widely to any deity or sage, regardless of their relative fame. The monk Jōkanbō featured in Shasekish ū corresponds to a historical figure, namely, Keien 慶円 (also read Kyōen, 1140-1223), a famous monk of the Shingon Sect 真言宗, and founder of Miwa Shintō 三輪神道, which attempts to unite the teachings of Shingon Buddhism with certain elements of Shintō. Keien was referred to by the honorific title Miwa shōniō 三輪上人, the Sage of Miwa.

According to Keien's biography, Miwa shōnin gyojō 三輪上人行状 (The Life and Work of the Sage of Miwa, 1253), the shrine in question was not located on Mt. Kinbu, but Iwashimizu hachimangū Shrine 石清水八幡宮, located in modern-day Yawata City 八幡市, Kyoto Prefecture. Keien, having overseen a burial, and thus deeming himself impure and unworthy of approaching the god, decides instead to make his religious offerings in Baba 馬場, a small region located at the foot of the mountain. As the sage is engaged in worship, a young layman possessed by the god of Iwashimizu hachimangū Shrine approaches, informing the monk that the god, far from condemning his actions, commends his decision to bury an unknown corpse: "You have committed no violation whatsoever." Keien is then encouraged by the deity to proceed to the shrine as initially planned. Standing before the altar, Keien and the deity transmit to each other secret knowledge of Buddhist inmyo 印明, that is, esoteric teachings pertaining to the use of mudras (insō 印相) and mantras (myöju 明呪, or shingon 真言). It is during this process of mutual transmission between man and god that the true identity (bonji 本地) of the latter is at last revealed. ${ }^{16}$ This account, as preserved in Miwa shōnin gyojo,

\footnotetext{
${ }^{16}$ According to the then prevalent theory of honji suijaku 本地垂迹, “ultimate reality and temporary manifestation," Shintō deities were understood to be temporary manifestations or "traces" (suijaku) of Buddhist divinities or "fundamental entities" (bonji). The buddhas, wishing to lead Japanese people to enlightenment, came in the form of more familiar Shintō deities. This is, of course, an extension of the well-known doctrine of expedient means (böben 方便). It was not always clear to which Buddhist divinity a particular Shintō deity corresponded. In these cases, it was necessary for a sage like Keien to somehow incite the Buddhist divinity to reveal his or her true identity. [Translator's note]
} 
serves as a foundational legend explaining the unique origins of Miwa Shintō as something that took place by way of the mutual transmission of esoteric knowledge between a sage and a deity.

\section{2-3. Two Tales of Tainted Sages at Hachimangū Shrine}

Miraculous legends centered around the Shintō deity Hachiman 八幡神 and his sacred abode, the aforementioned Iwashimizu hachimangu Shrine, in which a Shintō god reveals his true Buddhist identity as the direct result of some sage who has violated conventional prohibitions against ritual pollution, were in circulation as early as the beginning of the medieval period. Miyadera junpaiki 宮寺 巡拜記, or A Record of Pilgrimages to Various Shrines and Temples, a document compiled sometime around the first half of the thirteenth century, contains an account of a sage by the name of Chūrenbō 仲蓮房, about whom we know next to nothing, save that he was, according to this same document, something of an outsider (gairai no so 外来の僧), the precise meaning of which is unclear. On his way home from the shrine, Chūrenbō comes across an abandoned corpse. Out of compassion for the deceased, the sage hoists the corpse over his shoulders and proceeds to throw it by the riverside, away from the main thoroughfare. Ashamed at the ritual pollution of having come into direct contact with a dead body, and yet unwilling to wholly abandon his pilgrimage to various shrines around the area, Chürenbo decides to pass the night in the shrine's outer veranda, close enough to worship and far enough away not to offend the gods. The god Hachiman appears to a slumbering Chürenbō in the form of a Buddhist monk, informing him that his compassionate actions have won the god's praise: "I appear before you now, having been deeply moved by your compassionate act." This miraculous tale ends by informing us that Chūrenbō not only received divine approval for his actions, but was furthermore vouchsafed rebirth into the Pure Land. Here, too, we are told that Hachiman made the following declarations: "My original vow to rescue all sentient beings is one of compassion," and "I do not abhor the polluted and the unclean." The tale of Chūrenbō, then, was included as a means of explaining the initial circumstances surrounding these divine declarations.

The tale of Chürenbō appears again in a document compiled in the early fourteenthcentury entitled Hachiman gudōkun 八幡愚童訓, or Hachiman for Children. ${ }^{17}$ This work contains a chapter called "Impure Things" (fujo no koto 不浄事), which is dedicated to demonstrating Hachiman's utter disgust for all things impure. Interestingly, the tale of Chūrenbō is included in this chapter not, as it was in Miyadera

\footnotetext{
${ }^{17}$ This particular work has come down to us through two lineages of manuscripts- the köhon 甲本 lineage, or lineage A, which was completed between 1308-1318, and the otsubon 乙本 lineage, or lineage B, completed sometime between 1299-1302 - the contents of which show a number of significant differences. Abe is here referring to a version of Hachiman gudökun belonging to the köhon lineage. [Translator's note]
} 
junpaiki, as a way of showing that Hachiman does takes no offense to those who have come into contact with conventionally impure things, so long as they have done so out of compassion, but rather as an example of an exception to the rule. What Miyadera junpaiki takes as its central message, Hachiman gudōki includes as a curious exception. No less interestingly, while Miyadera junpaiki makes special note of the fact that Chürenbō is an outsider, Hachiman gudōki includes no such description. For the compiler of this later document, Chürenbō is just another monk; there is nothing exceptionally special about him. It was in virtue of this sage's compassionate heart, we are told, that he had no need to fear the otherwise deleterious effects of pollution.

This tale of the deity at Iwashimizu hachimangū Shrine applauding the actions of what would otherwise conventionally be condemned as a tainted sage appears, as has just been shown, in two opposite contexts. The reason for this is not overly complicated: In the medieval period, each powerful religious institution had, as its foundation, a set of prohibitions against ritual pollution-known, when canonized in writing, as bukkiryo 物忌令, ordinances pertaining to ritual pollution. It was this set of ordinances that ultimately served to legitimize the unique position of a given religious institution. Considering the importance of prohibitions of this sort, each institution endeavored to present what might pass for a logical explanation regarding the origin of their ordinances. Anecdotal tales, with their mythological motifs and conceptualizations of the world, were recruited as a means of satisfying this demand.

These miraculous tales were used by medieval religious institutions as a vehicle for inculcating in their audiences the perceived nature of their gods. On the one hand, the sage, who is usually portrayed as an outsider in some respect, commits two transgressions: First, moved solely by compassion for the suffering of others, he willingly comes into contact with some form of potentially polluting object. Second, though now in an impure state, he ignores all prohibitions against approaching the divinities, and boldly approaches the altar, trusting wholly in the god's mercy and understanding. ${ }^{18}$ On the other hand, the deity is portrayed as not only refraining from punishing the tainted sage, but as praising him. Medieval Shintō deities are portrayed as Buddhist divinities who have, in virtue of their infinite compassion for mankind, deign to appear in the guise of familiar forms, ready to forgive men for their trespasses so long as these trespassed were made out of compassion. It is possible to see in these tales a focal point through which may be descried a fundamental type of liminality, or an approach towards liminal space.

\footnotetext{
${ }^{18}$ Abe Yasurō 阿部泰郎, Yuya no kōgō: chūsei no sei to seinaru mono (Nagoya Daigaku Shuppankai, 1998), 50-64; Abe Yasurō 阿部泰郎, “Kumanokō” 熊野考, in Seisha no suisan: chüsei no koe to woko naru mono 聖者の推参—中世の声とヨコなるもの (Nagoya Daigaku Shuppankai, 2001), 214-220.
} 


\section{Tainted Sages in Holy Sites: The Socialization of Border Crossing}

\section{3-1. The Spread of Tales about Tainted Sages Who Visit Shrines}

During the latter half of the medieval period-from the Northern and Southern Courts (1336-1392) to the Muromachi period (1392-1573) — miraculous tales of tainted sages who had nevertheless visited holy sites, where they were consequently praised by the local deity, gradually became to take on a more concrete, more realistic form. Instead of fictional protagonists, these latter tales feature known historical personages, most of whom, significantly, are Buddhist monks. True, examples of tales containing well-known Buddhist monks, such as Keien, were circulated during the first half of the medieval period. However, as with Keien, these monks were generally portrayed as semi-mythical characters and not as strictly historical personages. Examples of tales from the latter half of the medieval period whose protagonists are historical Buddhist monks may be found in the accounts of ascetics belonging to the Zen and the Ritsu Schools, monks of the Jishu Sect 時衆, and various sages associated with the True Pure Land Sect 浄土真宗.

One such example is found in the person of Shigyoku 志玉 (1383-1463), a Zen monk learned in the Vinaya (ritsu 律) or monastic regulations, who also lectured on the Avatamsaka Sütra (Flower Garland Sutra; J: Kegonkyo 華㛜経), and who served as the head of the Kaidan'in 戒壇院, or Hall of the Ordination Platform, at Tōdaiji Temple 東大寺, and who, having spent some five years studying in China, was well-versed in the doctrines of the Huayan (J: Kegon) School 華厳宗. It was this same Shigyoku who compiled a religious commentary for Rokurin icbiro no ki 六輪一露之記 (An Account of the Six Wheels and the Single Dewdrop, c. 1455), a treatise on $n \bar{o}$ performance by the famous playwright Konparu Zenchiku 金春 禅竹 (1405-1471). The primary source for biographical information about this monk is found in Denritsu zugen kaishü 伝律図源解集 (Collected Commentaries on the Lineage of the Transmission of the Ritsu Sect, 1684), compiled by Jūkei 重慶 (n.d.) a monk based in Tōdaiji Kaidan'in 東大寺戒壇院. ${ }^{19}$ According to this source, Shigyoku played an active role in religious services conducted at Byakugōji Temple 白毫寺, in Nara, a temple for monks of the Ritsu School that contained a large cemetery. One day, having burnt incense at this temple on behalf the deceased, Shigyoku proceeded to pay his respects to the Shintō deity worshipped at Kasuga Shrine 春日社. Upon arriving at the altar, the heavens suddenly become ominously dark. Then, from out the sanctuary emerges an awe-inspiring apparition: the avatar of the shrine attired in formal court dress. The avatar upbraids Shigyoku for visiting his shrine so soon after having come into contact with the pollution of

\footnotetext{
${ }^{19}$ Funata Jun'ichi 舩田淳一, “Shie to jōbutsu—shingonkei shintōsho ni miru sōsō girei” 死穢 と成仏一真言系神道書に見る葬送儀礼，in Shinbutsu to girei no chūsei 神仏と儀礼の中世 (Hōzōkan, 2011), 288-289; a printed version of Denritsu zugen kaishü is contained in volume 64 of Dainihon bukkeyō zensho 大日本仏教全書 (Tokyo: Kōdansha, 1972).
} 
death. Unshaken, Shigyoku replies by intoning a Buddhist verse from Yuanjuejing 円覚経 (J: Engakukyo, likely late $7^{\text {th }}$-early $8^{\text {th }}$ century), the Sutra of Full Realization, effectively turning the tables and asking whether it is not the deity who is in the wrong. Is it not the case, retorts Shigyoku, that you, a divine being who has remained so long among us mortals, have forgotten your original vow of compassion towards all mankind? The deity, reminded of his vow, repents at once: "Indeed, it is as you say: I had forgotten the very doctrines [of compassion towards mankind] I myself once preached. I have mingled with the dust of this world for too long." Here we see a Buddhist monk leading a deity towards enlightenment, castigating him for having forgotten his original vow. The deity, we are made to understand, was in the wrong for accusing the monk of being polluted. In this tale, Shigyoku's supposed pollution is employed as a foil, by means of which the deity — and by implication readers of this tale - is brought towards a higher understanding.

Another similar account appears in the foundation legend of Iwata enmyōji Temple 岩田円明寺. This temple was founded by Kakujō 覚乗 (1272-1362), a monk of the Ritsu School based in Saidaiji Temple 西大寺. Kakujō was active throughout the region surrounding Ise Shrine 伊勢神宮 (in modern-day Ise City, Mie), and was consequently involved with rituals pertaining to the worship of Shito deities and discussions about Shintō religion in general. ${ }^{20}$ As the tale goes, Kakujō, having set his mind on establishing the aforementioned Iwata enmyōji Temple expressly as a family temple (ujidera 氏寺) for the priests at Ise Shrine, desired to know the original nature-honji 本地 or shintai 真躰—of the deity worshipped at that Shrine. That is to say, he wished to know the true identity of the Buddhist divinity who had assumed the disguise of a Shintō god. To this end, Kakujō vowed to pay his respects to the shrine for one-hundred consecutive days, a practice we have already encountered in previous sections. On the one-hundredth day, just as Kakujō was about to fulfil his vow, he was asked to administer the final rites to an unfortunate traveler who had since perished. Despite conventional prohibitions against ritual pollution, he agreed to administer the desired rites. Shortly thereafter, as Kakujō made his way through Miyakawa no hotori 宮川の畔 (in modern-day Ise City), a sacred space associated with local Shintō deities, an elderly man appeared before him, scolding the monk for stepping on holy ground in a tainted state. Kakujō, having responded with "the pure heart knows no taint," nevertheless turns about and prepares to return the way he came, not wishing to offend the deities. At this point, the deity himself appears before Kakujo in the form of a child, and apologizes for having wrongly accused the monk of violating prohibitions about ritual pollution: "Do not go! It was I, it seems, who forgot [my vows of compassion]. I have mingled in this

\footnotetext{
${ }^{20}$ This account of Kakujō is preserved in a document entitled Sanböin kyüki 三宝院旧記, or Old Records of the Hall of Three Treasures (likely completed sometime around the beginning of the seventeenth century), which is itself found in Dainihon shiryō大日本史料, 6:24.
} 
world of dust for too long." After reciting a Buddhist verse relating to the purity and unconditional compassion entailed in the deity's original vow, he announces to Kakujō a new covenant, namely, that all believers who make a pilgrimage to Iwata enmyōji Temple will be freed of all taint.

After receiving this first revelation, Kakujō is blessed with a second, this time in the form of a dream, in which he is commanded to visit the altar once again. Once at the altar, Kakujo is greeted by a snake-actually the divinity in disguise-who emerges from the shrine's pond. After reverently paying his respects to this serpent, he promptly throws his monk's robe over its body. Incidentally, according to this tale, the practice of carving serpent seals (jagyō no ban 蛇形判), stamps decorated with the image of a snake, first began when Kakujō carved a likeness of this divine snake. While this is not the place to enter into details, suffice it to say that Kakujō, in an effort to uncover the true (Buddhist) identity of the divinity at Ise, travels from Anōtsu 安濃津, or Anō Port, in modern-day Tsu City 津市, Mie, to Futamigaura 二見浦, or Futami Bay, in modern-day Ise City, Mie. It is at a temple located close to Futami Bay that Kakujō at last receives his long-sought revelation: the deity at Ise is none other than Amida 阿弥陀 himself, as worshipped at Kōdera Temple 国府寺, located in modern-day Kōmura 国府村, Suzuka City 鈴鹿市, Mie. When Kakujō eventually makes his way to Kōdera Temple, whereupon the Buddhist statue, usually hidden from view, is brought out for him to inspect, he discovers draped over its shoulders the very robe he cast over the aforementioned snake. This evidence is conclusive. In this manner, then, Kakujō was able to incite the deity at Ise Shrine to reveal his true identity.

Kakujō was the author of, Tenshō daijin kuketsu 天照太神口決 (Oral Transmission Pertaining to the Great Goddess Amaterasu, 1328), a treatise aimed at promoting a then popular doctrine known as shinbutsu shügö 神仏習合, in which Shintō deities were intimately merged with complementary Buddhist divinities. Naturally, Kakujō was especially interested in championing this doctrine insofar as it pertained to Amaterasu 天照, the presiding goddess at Ise Shrine. In this relation, Kakujō also promulgated a foundational legend pertaining to the esoteric ordination rites (sokuihō 即位法) used at his temple. ${ }^{21}$ As may be seen, Kakujō exerted significant influence over contemporary discussions about the relationship between Shintō and Buddhism. Most obviously, he played a central role in promoting the distribution to all visitors - theoretically monks and sages-at Iwata enmyōji Temple of magical amulets ( $g o f u$ 護符) believed to cleanse their bearers of all ritual pollution. What Kakujō promoted was essentially a system of symbolic transference

\footnotetext{
${ }^{21}$ Abe Yasurō 阿部泰郎, “Iruka no seiritsu”「入鹿」の成立, in Geinōshi kenkyū 芸能史研究, 69 (1980), 1-18. For a discussion of Kakujō’s Tenshō daijin kuketsu, see Abe Yasurō 阿部泰郎, "Chūsei shūkyō shisō bunken no kenkyū (1): Ninnajibon Tenshō daijin kuketsu no honkoku to kaidai”「中世宗教思想文献の研究（一）「仁和寺本『天照大神口決』の翻刻と解題, in Nagoya daigaku bungakubu kenkyū ronshū bungaku 名古屋大学文学部研究論集 文学, 43 (1997), 193205.
} 
whereby the power to purify or cleanse from pollution became enshrined within small, portable artefacts.

\section{3-2. The Role of the Sage at Ise Shrine}

The tradition of tainted sages visiting Ise Shrine, home of what were then seen as Japan's highest divinities, was inaugurated by the aforementioned Kakujō. It was during the end of the Muromachi period, with the composition of a certain illustrated scroll entitled Kokua shōin eden 国阿上人絵伝, or, the Illustrated Biography of Master Kokua (possibly completed between 1573-1600), that this same tradition gained increased social credence. ${ }^{22}$ Kokua 国阿 (1314-1405) was the founder of a particular branch of the Jishu Sect known as the Ryōzen School 霊山派, based in Shōhōji Temple 正法寺, Kyoto. Being an itinerant monk, he travelled widely throughout Japan. Kokua paid his respects to Ise Shrine on a number of occasions, eagerly spreading his teachings throughout that particular area. According to the third fascicle (section nos. 17-20) of Kokua shonin eden, Kokua, feeling sympathy for those people whose ritual pollution-especially that of menstrual blood-barred them from visiting Ise Shrine, vowed to visit the shrine every day for one-thousand consecutive days, in hopes that the deities might find it in their hearts to forgive the sin of pollution found in those who paid their respects to the shrine. On the final day of his austerities, Kokua spied the putrefying corpse of a leper victim floating on Mimosuso River 御裳濯河, a river, now known as Isuzu River 五十鈴川, which flows through the Inner Sanctum (Naikū 内宮) of Ise Shrine. Moved by pity, Kokua performs the final rites on behalf of the deceased. No sooner has he completed these rites when the corpse suddenly takes on the appearance of the bodhisattva Kannon 観音, and, soaring into the sky, announces to the sage that his vow has been granted. The leper-turned-divinity motif is one we have already encountered in the tales of the Chinese monk Xuanzang (J: Genjō) and the Japanese empress Kōmyō.

As the story goes, Kokua, upon approaching the precincts of the shrine, is greeted by none other than the great sun goddess Amaterasu herself-albeit not in her native form but through a female medium serving in the shrine-who directs the sage to approach the sacred altar. There, Kokua is further greeted by a divinity known as Uhō dōji 雨宝童子, who presents him with the leaf of a kashiwa 柏, or Japanese emperor oak, as a sign that the sage's vow has been divinely sanctioned..$^{23}$ In the medieval period, a particular species of this leaf, the

\footnotetext{
${ }^{22}$ Washio Junkyō 鷲尾順敬, Kokubun tōbō bukkeyō sōsho 国文東方仏教叢書, second series, volume 5, “biographies” 伝記部 (Tōhō Shoin, 1928), 355-357.

${ }^{23}$ Uhō dōji, literally, the youth (doji) of raining or showering treasure (uhö), a divinity depicted as holding a staff in his right hand and a rosary in his left, was understood to represent the embodiment of Amaterasu when she first descended to Hyūga 日向, in modern-day northern Miyazaki. Alternately_ and this amounts to the same thing in the end-Uhō dōji was taken to be a temporary manifestation of Dainichi nyōrai 大日如来, the Great Sun Buddha (Sk: Mahāvairocana), who was, in turn, thought to be the honji or Buddhist reality of Amaterasu. [Translator's note]
} 
tip of which ended in three distinct points, and which was consequently known as the mitsunagashiwa 三角柏, or triple-tipped emperor oak, served as an esoteric representation of the goddess Amaterasu. ${ }^{24}$ Examining the leaf, Kokua discovers the following words stamped upon its upper surface: "The sins of ritual pollution for all those who pay their respects to the shrines along Ise and Kumano shall be forgiven for all eternity." We are told that Kokua, having copied the image of this divine stamp, had paper copies printed for all those, ecclesiastics and layfolk alike, who visited the shrine. Thereafter, the miraculous efficacy of Ise Shrine was encapsulated in the following proclamation: "All unavoidable ritual pollution accidentally encountered along the way to the shrine shall be forgiven, and one's wish to visit the shrine shall be duly granted." 'Trusting in this proclamation, visitors to the sacred site established by Kokua at Ise Shrine would receive a series of ten invocations along with a copy of the divine stamp (ofuda ふふだ). This invaluable stamp came to serve, in effect, as an indulgence or certificate of religious vindication for pilgrims. According to Kokua shönin eden, these events occurred during the first year of Eiwa 永和, that is, in 1375.

Practically speaking, this biography of Kokua serves as a foundational tale (engi) aimed at explaining the miraculous origins of the divine stamp distributed to those pilgrims visiting the Shōhōji Temple in Higashiyama 東山, Kyoto. Incidentally, Shōōji continues to hand out copies of the "divine stamp of the emperor oak" (kashiwaba no shin’in 柏葉の神印) to this very day. Kokua's biography is an encapsulation of the entire process leading up to the creation of salvific artefacts. Through his continued austerities and sincere compassion, Kokua was able to move the goddess Amaterasu to bestow her divine favor on all future pilgrims inadvertently tainted with ritual pollution. This was achieved, first and foremost, by a deliberate transgression of conventional prohibitions against ritual pollution. It was only after Kokua had intoned the final rites on behalf of the leprous corpse, thereby making himself susceptible to the pollution of death and disease, and proceeded to enter the sacred space of the altar-a space where even the faintest taint should not be permitted - that Amaterasu rewarded the sage with blessings and a vision of herself in the form of Uhō dōji. Only then did the goddess relay to Kokua her divine proclamation stating once and for all that pilgrims who visited her altar were to be cleansed of any ritual pollution incurred on the way, and that by means of a divine stamp-essentially a magical talisman. As will be clearly seen from a comparison with the various tales of miraculous events and divine manifestations already discussed throughout this paper, the biography of Kokua has been sewn together out of a number of previously existing motifs.

\footnotetext{
${ }^{24}$ Itō Satoshi 伊藤聡, Chüsei Amaterasu ömikami shinkō no kenkyū 中世天照大神信仰の研究 (Hōzōkan 法蔵館, 2011). For the text of Mitsuna kashiwadenki 三角柏伝記, see Shimpukuji zenbon sōkean 真福寺善本叢刊, first series, volume 6, ryōbu shintōshū 両部神道集 (Rinsen Shoten, 1998).
} 


\section{3-3. Some Undercurrents in Tales of Tainted Sages at Kumano}

The message upon the divine stamp presented to Kokua by Amaterasu, it will be recalled, read as follows: "The sins of ritual pollution for all those who pay their respects to the shrines along Ise and Kumano shall be forgiven for all eternity." Here we see two holy sites, namely, Ise and Kumano, mentioned side by side. In the beginning of the medieval period, it was believed that the presiding deity worshipped at Kumano was the same deity worshipped at Ise. These two sites were seen as belonging to a single circuit of holy spaces. Itinerant nuns who preached at and around both sites espoused this paradigm. Kumano, even more so than Ise, was championed as a sanctuary par excellence: As has already been seen in Ippen bijiri'e, the sage Ippen received a divine proclamation from the avatar of Kumano that effectively eradicated any fundamental distinctions between purity and impurity supposed to have resulted from ritual pollution. Those who visited Kumano were cleansed of any pollution; pilgrims were saved so long as they made their way to the sanctuary that was Kumano. This belief in the salvific power of Kumano is indicative of something deeper, namely, of a transformation during the medieval period in the way in which the nature of deities was envisioned.

The deity at Kumano not only cleansed pilgrims of all previous sin and pollution, but furthermore guaranteed a spiritual rebirth, a new life of renewed purity and sanctity, to all those who placed their unconditional trust unconditionally in the deity's power. Salvation, therefore, was no longer thought to depend upon the intensity of one's own faith, but instead came to be seen as a more-or-less vicarious gift of divine grace emanating from the power inherent in the deity's original vow (bongan 本願) of compassion towards all mankind. The salvific function of medieval deities, rooted as it was in the deities themselves, transcended conventional distinctions between faith and unfaith on the part of believers. This is not to say, however, that pilgrims to Kumano, trusting in the divine grace of the presiding deity, could flout prohibitions against ritual pollution with impunity. Pilgrims making their way to Kumano had to observe strict austerities; the trek to the holy site was itself a prolonged ritual, during the whole of which pilgrims strove to avoid all taint of ritual pollution, and thereby preserve religious purity; numerous conventions and proscriptions, established in the hoary past by those who had made the journey before, dictated and circumscribed much of the pilgrim's behavior while travelling along the road. ${ }^{25}$

Kumano, now popularly regarded as the holiest site in all of Japan (Nibon daiichi reigenjo 日本第一大霊験所), has come to embrace within itself two extremes: On the one hand, the deity at Kumano has guaranteed salvation to all who come,

\footnotetext{
${ }^{25}$ For a contemporary account of these matters, see the twelfth-century anthology Shozan engi 諸山縁起, or Foundational Tales of Various Holy Mountains, especially the document found therein entitled En no gyoja Kumano sankei nikki 役行者熊野参詣日記, or Pilgrimage to Kumano: The Diary of En the Ascetic.
} 
regardless of what pollution they might have incurred on the way. On the other hand, however, these same pilgrims are under the strictest obligations to maintain ritual purity throughout the entire journey. Divine grace comes side by side with severe prohibitions. ${ }^{26}$ Likewise, pollution comes side by side with purity. As was the case with Ippen at Kumano and Kokua at Ise, it is the arrival of a tainted sage within the holy precincts that miraculously brings about the creation of a holy relic. Tales of this sort were spread throughout eastern Japan, where belief in the miraculous power of the deity at Kumano was strong, primarily by itinerant monks (nenbutsu hijiri 念仏聖) who preached the salvific effects of chanting the name of Amida. For these monks, too, it was not the faith of the individual that saved, but the divine power of Amida's original vow.

\section{3-4. Contrasting Perspectives in Tales of Hei Tarō: the True Pure Land Sect}

Shinran 親㝈 (1173-1263), founder of the True Pure Land Sect (Jōdo shinshū 浄土真宗) of Buddhism, had a disciple by the name of Shinbutsu 真仏 (?-1262) who served as a leader in the spread of Shinran's teachings throughout eastern Japan. A religious primer (dangibon 談義本), written in a combination of Sinitic characters and hiragana, and entitled Shinran shönin goinnen 親鸞聖人御因縁, or $O n$ the Origins of Master Shinran, was widely circulated among believers during the early phases of Shinran's sect, that is, during the end of the Kamakura period. ${ }^{27}$ This primer contains a section, bearing the title "Shinbutsu innen" 真仏因縁, that is, "On the Origins of Shinbutsu," which states that Shinbutsu originally hailed from a family of farmers based in Yokosone 横曾根, Hitachi 常陸 (modernday Ibaraki), and that his secular name had been Hei Tarō 平太郎. Hei Tarō learned two things from Shinran: First, the practice of constantly intoning the name of Amida as a means of ensuring salvation; second, the doctrine that the Japanese deities are actually Buddhist divinities who have somehow become spiritually lost, and that, consequently, one who dedicates his life to reciting Amida's holy name ought not pray to such fatuous beings. On one occasion, Hei Tarō was ordered to accompany Lord Satake 佐竹殿, a powerful local proprietor of the domain (ryōshu 領主), on a pilgrimage to Kumano, during which journey Tarō was to serve in the capacity of a hired servant. His behavior on the road, however, was less than pleasing to his lord. Not only did Hei Tarō refuse to observe the traditional rules and proscriptions, preferring instead to focus his energies on intoning the name of Amida, he even went so far as to offer a beggar rice that had been cooked over a ritually purified fire (imibi 忌火) used exclusively

\footnotetext{
${ }^{26}$ Maruyama Shizuka 丸山静, Kumanokō 熊野考 (Serika shobō, 1984); Abe Yasurō 阿部泰郎, “Kumanokō" 熊野考, in Seisha no suisan: chüsei no koe to woko naru mono 聖者の推参一中世の声と ヨコなるもの (Nagoya Daigaku Shuppankai, 2001), 214-220.

${ }^{27}$ Miyazaki Enjun 宮崎圓遵, Bukkeyō bunkashi no kenkyū 仏教文化史の研究 (Nagata Bunshōdō, 1989), 199-201.
} 
in preparing offerings destined for the gods. Nor did he refrain from eating meat and other otherwise prohibited victuals. Finally, he flouted all convention by hiding - that is, burying with his own hands-a corpse that had been washed up on the beach.

Having at last arrived at the shrine, Lord Satake and his men lay down before the main altar to recover from the arduous trek. Incredibly, all of the men are visited by the same dream, one in which the avatar of the shrine pays his respectful obeisance to none but Hei Tarō. Lord Satake is understandably perplexed. Why, complains he, did the deity not bow to himself? Why would a deity offer his blessings to a man who chose to flout all conventions of ritual purity? In response to these complaints, the deity explains how it was in virtue of the miraculous efficacy of Amida's name, as intoned by Hei Tarō, that this deity was able at long last to find liberation from the three tribulations (sannetsu 三熱 or sankan 三患) that habitually plague benighted souls. "You men shall know this god's true identity when I reveal my Buddhist origin (honji)," declares the deity, concluding with the following divine verses, in the vernacular: "All men, be they among the lowly or be they among the high-born-now all men alike may become buddhas, so long as they intone the name of Amida!"29 The men, their eyes now open, immediately pay homage to Hei Tarō, causing him to take the tonsure before the altar, and givng him the Buddhist name Shinbutsu, that is, the True Buddha. On the journey back home, so the story goes, Shinbutsu preached (kanjin 勧進) to some twenty-thousand souls, the great majority of whom were moved to donate wealth or labor to various Buddhist-related building projects.

The prohibitions this layman-turned-sage flouted on his way to Kumano were not restricted to coming into contact with the pollution of death, but extended more generally to all the time-honored conventions and proscriptions usually prescribed for pilgrims. The textual style of "Shinbutsu innen," being a religious primer (dangibon) aimed at a popular audience, is characteristically colloquial and straightforward. A complete disregard for, and sometimes even outright mockery of conventional prohibitions on the part of Shinbutsu, acting here as a representative of all who profess to be dedicated intoners of Amida's name, is depicted in a lively manner. In this respect, Shinbutsu is another example of a broader motif found in many medieval tales, where an ostensibly foolish protagonist turns out to be a sage, a genuinely “enlightened fool” (sei naru gusha 聖なる思者). The world of

\footnotetext{
${ }^{28}$ These three tribulations (sankan), or three burning afflictions (sannetsu), most commonly described as afflicting, among other things, dragons and snakes, are enumerated as follows: scorching winds (neppü 熱風) that burn a creature's flesh and bones; violent gusts (akufü 覀風) that blow away a creature's shelter and any vestments he might have; the pain of being eaten alive by a flaming mythical bird known, in Sanskrit, as Garuda (J: Konjichō 金翅鳥). [Translator's note]

${ }^{29}$ The original text of this poem reads as follows: Iyashiki mo / yoki mo ima wa / oshinabate / namuami dabutsu to / iu wa botoke zo 卑きも良きも今はおしなべて南無阿弥陀仏と云ふは仏ぞ.
} 
Muromachi-period popular vernacular tales (otogi zōshi 御伽草子) has no shortage of such enlightened fools: The protagonist of Kootoko no sosshi 小男の草子, or the Tale of the Little Man, as well as that of Monokusa Tarō 物くさ太郎, or Lazy Tarō, are both described as country bumpkins whose unexpected wit, especially in the world of vernacular poetry, leads them to unrivalled wealth and success in the capital. ${ }^{30}$

"Shinbutsu innen," as preserved in Shinran shonin goinnen, is not the only version we have of a tale relating to the origins of Shinbutsu. A monk by the name of Kakunyo 覚如 (1270-1351), recognized as Shinran's immediate successor, compiled a biography of his master entitled Zenshin shōnin Shinran denne 善信聖人 親鸞伝絵, or the Illustrated Biography of Master Zenshin, aka Shinran (1296), the perspective of which is quite contrary to that found in "Shinbutsu innnen." The story of Hei Tarō, which is woven into the second fascicle of this work, begins in the same manner as "Shinbutsu innen": Hei Tarō, deeply moved by the teachings of Shinran, pays no heed to the conventional rituals prescribed for pilgrims, and wholly ignores all prohibitions against impurity during his journey to Kumano. It is the next episode that makes the version of Shinbutsu's life as told in Zenshin shönin Shinran denne that presents us with a most striking contrast. In this version of the tale, Hei Tarō, having fallen asleep in front of the altar, is visited in a dream by the avatar of the shrine, who proceeds to castigate the man for blatantly transgressing all the conventional religious prohibitions. This ought to remind us of the tales of Shigyoku and Kakujō already mentioned. Suddenly, the figure of Shinran appears seated across the avatar, explaining to the latter that Hei Tarō is one of his own disciples, and that he is sincerely following the way of one who dedicates his life to intoning the name of Amida. The avatar, now pacified, bows low towards Hei Tarō. In this version of the tale, Hei Tarō is merely a subsidiary character serving to introduce the teachings of Shinran; being but a passive observer, in the dream world, of a conversation between Shinran and the avatar, Hei Tarō ends up as nothing more than a middle man. Consequently, all traces of the tainted sage who, due to his compassion for mankind, consciously ignores religious prohibitions in order to pay his respects to a given deity are entirely wanting. Rather, what we have with this second version is something akin to a mythical tale about Shinran as founder of a unique sect of Japanese Buddhism. In later ages, such tales, known collectively as Godenshō 御伝鈔 (Episodes from the Life of Our Master), were regularly read aloud during commemorative ceremonies (hoonkō 報恩講) dedicated to Shinran. This shift in perspective is even more drastic than that seen above with regards to the depiction of the sage at Iwashimizu Hachiman Shrine and the text of Hachimangu dokeun.

\footnotetext{
${ }^{30}$ Satake Akihiro 佐竹昭広, “Nariagari”成り上り, in Gekokujō no bungaku 下攰上の文学 (Chikuma Shobō, 1962).
} 


\section{Conclusion}

The world of medieval Japanese tales and legends is full of dramatic border crossings. As may be seen, for example, from the manner in which artists of illustrated scrolls were able to depict single scenes with vivid detail, these border crossings present readers and viewers with an intense and lasting impression. The feeling of surprise consequent upon looking at such works of art encourages us to visualize anew the nature of borders as depicted in medieval Japanese literature and art. These borders were far from simple or monolithic entities; each border was the product of a complex network of various interrelated elements, including social, cultural, religious, and ethnological factors. Some of these borders were relatively less complicated, such as those holy sites that prohibited women from entering, simply on the grounds that they were women, and potential objects of sexual desire. Tales of women who, disguised as men, dared to trespass into these sacred spaces, along with depictions of these border crossing in the performative arts, may all be seen as varied manifestations of the sort of blurring-which blurring is itself a cultural movement-invoked by any discussion of borders. Let us turn our attention to those male sages who are depicted as both the discoverers and establishers of sacred spaces. When faced with the dilemma of how best to deal with a woman, these sages exhibit a number of varying responses: at times the sage, pursued by an impassioned female, succeeds in escaping; at other times, to the contrary, the sage goes so far as to request sexual intercourse. Whatever the reaction, these sages, insofar as they were religious figures, were responsible for fulfilling a specific role. Medieval tales and legends bear ample witness to this fact.

The sage who, moved solely by pity and compassion for his fellow creatures, deliberately transgressions religious proscriptions is not merely breaking his Buddhist vows of chastity and purity. In every instance, what he is breaking, even more profoundly, is some sort of border, a border that is inherently multifaceted and complex. The most deleterious sort of ritual pollution was that incurred through contact with death, especially by participating in anything relating to the burial of corpses. In Japan, from ancient times up until the present day, it was these male sages, the protagonists of numerous miraculous tales, who came to serve as functionaries of death, insofar as they were seen as mediators of funerals. It is this age-old function of sages that gave rise to the Japanese phenomenon commonly known as söshiki bukkeyo 葬式仏教, that is, the popular conceptualization of Buddhism as something more-or-less exclusively bound up with funerals and death. It is this role, also, that imposes upon sages the stigma of ritual pollution. The continual and inevitable existence of ritual pollution necessitates a sacred space into which such pollution must, at least theoretically, never be permitted to enter. Thus arose the role of the shrine, and of the deities enshrined therein: the shrine is a place charged with maintaining the boundary between the profane and the sacred, the polluted and the pure. Indeed, the entire 
system of Shintoistic deities, at the apex of which stands Ise Shrine, is fundamentally incompatible with Buddhism-its monks, its doctrines, and even its terminology - for the simple fact that Buddhism was never directly concerned with those traditional prohibitions against ritual pollution prevailing throughout the archipelago.

Medieval tales and legends, however, blur the boundary between Shintoistic shrines and Buddhist elements. In these tales, the sage is obliged to pay his respects to a shrine. Just when it seems that he will be able to make his way to the shrine in a pure state, however, he is made to come into contact with some form of ritual pollution. Consequently, this sage, as though controlled by some inexorable fate-of the sort most often found in mythical stories-is now forced to enter the shrine in a state of ritual contamination. For this very reason, it is in that climactic, decisive moment, when the deity blesses the tainted sage, that we see a miraculous border crossing, an epiphany characterized by the transformation from a polluted subject into a sacred or sagely subject. The deity, for its part, is no longer a vengeful, merciless judge bent on punishing the sage for some bygone sin, but rather a compassionate friend of mankind. The sage, having moved the deity to pity through his own compassionate actions, at once receives approval for his role as a medium between mankind and the gods, as well as receiving justification for his very existence. A new medieval concept of the sacred was forged from the furnace of tales and legends of this sort. However, as has been seen from the numerous cases discussed in this paper, this development was by no means a smooth and easy one. Rather, this new type of sacred purity is based on an extremely precarious and dubious species of liminality. It is this very precarious nature of the sacred that makes it susceptible to manipulation. The context of medieval tales of the sacred can be (and were) easily altered. We must always keep in mind the fact that texts dedicated to legitimizing a favored regime or sanctifying some charismatic figure were likely to manipulate the sacred as a means of furthering some ideological end.

\section{References}

Abe Yasurō 阿部泰郎, “Iruka no seiritsu” 『入鹿』の成立, in Geinōshi kenkyū 芸能史研究, no. 68 (1980).

Abe Yasurō 阿部泰郎, Seija no suisan: chūsei no koe to oko naru mono 聖者の推参 中世の声とヨコなるもの. Nagoya: Nagoya Daigaku Shuppankai, 2001.

Abe Yasurō 阿部泰郎, Yuya no koogō: chūsei no sei to sei naru mono 湯屋の皇后一中世 の性と聖なるもの. Nagoya: Nagoya Daigaku Shuppankai, 1998.

Funata Jun'ichi 舩田淳一, Shinbutsu to girei no chüsei 神仏と儀礼の中世. Kyoto: Hōzōkan, 2011.

Gorai Shigeru 五來重, Hijiri no keifu to shomin bukekyo 聖の系譜と庶民仏教. Kyoto: Hōzōkan, 2007. 
Gorai Shigeru 五來重, Kōyahijiri 高野聖. Tokyo: Kadokawa Shoten, 1975.

Hori Ichirō 堀一郎, Küya 空也. Tokyo: Yoshikawa Kōbunkan, 1963.

Hori Ichirō 堀一郎, Wagakuni Minkan shinkōshi no kenkyū 我が国 民間信仰史の研 究. Tokyo: Tōkyō Sōgensha, 1955.

Itō Yūshin 伊藤唯真 Hijiribukekyōshi no keenkyū 聖仏教史の研究. Kyoto: Hōzōkan, 1995.

Maruyama Shizuka 丸山静, Kumanokō 熊野考. Tokyo: Serika Sobō, 1989.

Miyazaki Enjun 宮崎圓遵, Bukkeyō bunkashi no kenkyū 仏教文化史の研究. Kyoto: Nagata bunshōdō, 1989.

Satake Akihiro 佐竹昭広, Gekokujō no bungaku 下攰上の文学. Tokyo: Chikuma Shobō, 1967.

Watanabe Sadamaro 渡邊貞磨, Bukkeyō bungaku no shüen 仏教文学の周縁. Osaka: Izumi Shoin, 1994. 